\title{
Notes
}

\section{The Fixed Easter Cycle in the Ethiopian Church}

\author{
Ekaterina V. Gusarova \\ Institute of Oriental Manuscripts of the Russian Academy of Sciences; \\ Manuscript Department of the National Library of Russia; National Research \\ University Higher School of Economics (St. Petersburg) \\ ekater-ina@mail.ru
}

\begin{abstract}
This article deals with the fixed Christian Easter and the feasts, which depend on it. Both moveable and fixed feasts are recorded in Christian calendars and synaxaria. Following the decisions of the First Oecumenical Council of Nicaea (AD 325) the Ethiopians celebrated mostly the moveable Easter and its cycle. At the same time in the Ethiopian Royal Chronicles is also recorded that the Ethiopian Kings and their armies celebrated the fixed Easter and its festivals, especially the Good Friday.
\end{abstract}

\section{Keywords}

Ethiopian Church - Alexandrian Church - Computus - Christian moveable and fixed feasts - Ethiopic calendar - fixed Easter - fixed Good Friday - Ethiopian Royal Chronicles

The tradition narrates that initially the Ethiopian clergy was not capable to calculate the Easter ( $\mathbf{4} \cdot \mathbf{n} \cdot \mathbf{h}:$ fasika) because this responsibility layed within the duties of Coptic Patriarchs of Alexandria. They annually idetified the dates of the Easter Festival and announced it to other Christian churches. As a result, 
the Ethiopians did obtain the computus information from Alexandria. Here it should be pointed to the fact that the Alexandrian Patriarchate was quite distant from the Horn of Africa and the journey from there to Egypt was difficult. Therefore, the contacts between the two Churches (or, rather, the Mother Church and its Metropolis) were scarce and irregular. The lack of normal connection caused numerous disruptions in nominating Metropolitans and made difficult the calculation of the Easter. ${ }^{1}$ The inability of the Ethiopian clergy to carry out the computus obviously was one of the major reasons for retaining of the fixed feasts in the Ethiopian Church, which celebrated them almost on the same level as their moveable counterparts.

The Ethiopians celebrate the fixed Easter day on the 29 of Maggabit (March

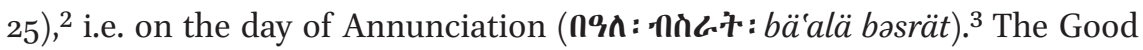
Friday is assigned to the 27 of Maggabit (March 23). ${ }^{4}$

It should be stressed that the fixed Easter and other feasts of the Easter $\mathrm{Cy}$ cle are mentioned, albeit scarcely, in the Royal Chronicles of medieval Ethiopia. The authors of these annals, however, provide rather limited information on this subject. Still in the historical writings from the late 18th century there are available some interesting details on how these festivals were celebrated.

In the Chronicle of the King Täklä Giyorgis ${ }^{5}$ it is mentioned that the military campaigns of this king were rather intermittent due to the big number of holidays connected to religious festivals. On the 27 of Maggabit (March 23, 1779) they did not fight, as the Christians of Ethiopia on that day celebrated the fixed Good Friday. In two days after it, on Sunday, took place the fixed Easter, which as usual coincided with the Annunciation. Moreover in that year the

1 See about the computus in Egyptian and Alexandrian traditions (and in early Christianity in general) in: A. Mosshammer Alden, The Easter Computus and the Origins of the Christian Era, Oxford - New York, 2008.

2 Here and below the dates in brackets are given according to the Julian calendar.

3 The article about the calendar of the Ethiopian Church in the Encyclopaedia Aethiopica says that on the 27 of Maggabit (March 23) the Ethiopians celebrate the fixed Easter day. This claim is not substantiated with exact evidences, whilst it is in full contradiction with all the Ethiopian sources available to me, where the above-mentioned feast falls on the 29 of Maggabit (March 25) (See E. Fritsch and U. Zanetti, "Christian calendar", in: S. Uhlig (ed.), Encyclopaedia Aethiopica, Wiesbaden, 2003, vol. 1, pp. 668-672 (p. 671)).

4 See, for instance: Iobi Ludolfi alias Leutholf dicti, Ad suam Historiam Aethiopicam antehac editam commentarius, Francofurti ad Moenum, 1691, p. 412; G. Colin, "Le Synaxaire Éthiopien. Mois de Maggābit. Édition critique du texte éthiopien et traduction française", PO 46, 3 (Nr 207), 1994, pp. 434-437.

5 He was reigning during six separate periods: in AD 1779-1784, 1788-1789, 1794-1795, 1795-1796, 1798-1799, 1800-1801. 
moveable Easter was very close to the fixed one: on Sunday, the 2 of Miyazya

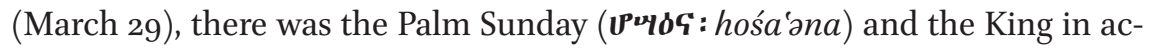
cordance with traditions ordered to prepare a great dinner for the Easter day:

"And on the 27 of Maggabit there was a rest in that place, since it was the beginning of the Crucifixion of our Lord, ${ }^{6}$ the glory be upon Him... and next day, on the 29 of Maggabit, there was a rest, since it was the feast of Incarnation... ${ }^{7}$ and on the 2 of Miyazya, on Sunday, the ras Ayadar and the princes came to the king and they spent the day in tasting food and drinks, since it was

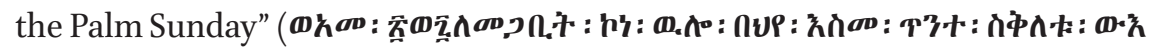

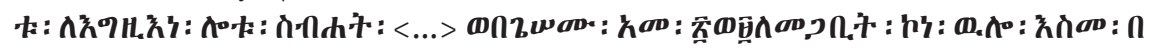

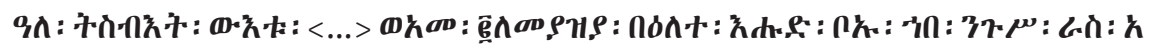

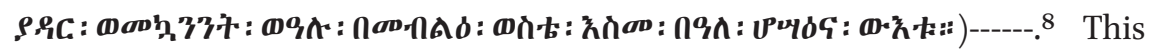
means that at the end of the 18th century, as probably in the centuries before the fixed Good Friday was celebrated at the Royal court of Ethiopia alongside with the moveable feasts of the Easter cycle. Certainly in the case of Good Friday the celebration consisted in mourning and abstention from fighting. As to the fixed Easter, it is hardly possible to differentiate its celebration from that of the Annunciation.

One has to say that the fixed Easters could precede the movable Easters or follow them. ${ }^{9}$ When the fixed Easter preceded the movable Easter the Great Lent could be interrupted..$^{10}$ The number of days, which separated two Easters could be either rather small or, of course, big. ${ }^{11}$

$6 \quad$ One of the names for the Good Friday used by the Ethiopians.

7 One of the names for the Annunciation used by the Ethiopians.

8 British Museum, ms. Orient. 821, fol. 457v, col. 1.10-2.18.

9 In AD 1591, for example, the Easter was celebrated on the 8 of Maggabit (March 3).

10 In AD 1782 the moveable Easter fell on the 21 of Miyazya (April 16). In the text of the Chronicle of Takla Giyorgis I we read that on the 29 of Maggabit (March 25) the king was feasting with his officers (in spite of the Great Lent) on the occasion to the Annunciation: "And on the 27 (of Maggabit), on Thursday, the king sent numerous troops to each region providing them with food for subsistence and granted mantles to churches... and on the 29 (of Maggabit), on Saturday, the king came to the church and granted priestly vestments to the church and on his return he spent the day with his princes in tasting food and drinks, since its was the (feast of) Incarnation" (British Museum, ms. Orient. 821, fol. 48or,

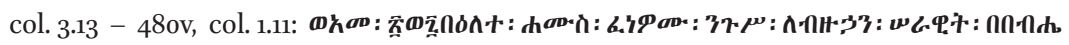

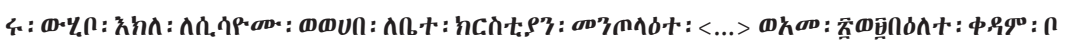
久 : ३7.

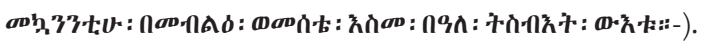

11 For example, in AD 1695 the moveable Easter fell on the 28 of Maggabit, one day before the fixed counterpart of the feast. 


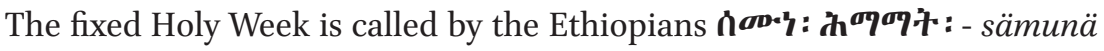
həmamat just as its moveable counterpart. On the eighth day after the Easter the Ethiopians celebrate the appearance of Christ before the Apostle Thomas

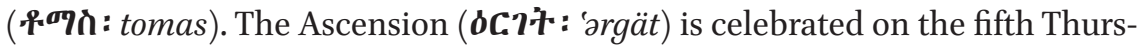
day after moveable Easter Sunday (on the 4oth day). The Pentecost is normally celebrated on the 5oth day. In the reality if the moveable Easter Sunday fell on the 9 of Miyazya (April 5), ${ }^{12}$ the Ascension was celebrated on the 18 of Gənbot

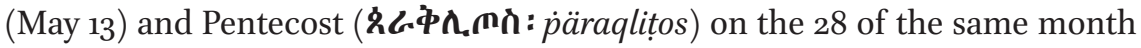
(May 23). On the days of the 27 of Maggabit (March 23) every year did fall the fixed Crucifixion (of the 27 of Maggabit (March 23) every year did fall the fixed Crucifixion (市市市: saqlät) ${ }^{13}$ day and on the 29 (March 25) the fixed Easter.

It seems that the Ethiopians did not celebrate the festivals of the Ascension (the 8 of Gənbot = May 3) and the Pentecost (the 18 of Gənbot $=$ May 13) $)^{14}$ on the fixed days although these dates are listed in the Church calendar. ${ }^{15}$ On the contrary they did celebrate the day of the so-called mid-Pentecost, $\boldsymbol{\delta} \boldsymbol{n} \boldsymbol{w}: \boldsymbol{L} \boldsymbol{n}$ n : - 'alätä räkab, as it is recorded in the texts of the Royal Chronicles. It is emphasized there that on this day in $\mathrm{AD} 1684$ it was decided to set an important meeting of the clergy and monks. ${ }^{16}$

12 In $\mathrm{AD} 1779$.

13 The Chronicle of the King of Kings Särșä Dangal (1563-1597) describes the 27 of Maggabit (AD 1587), Saturday, in the following words: "the day of liberation of the souls of Adam and his children from the slavery of the Devil and the power of the Hell" (E.G.) [C. Conti Rossini (ed.), Historia regis Sarșa Dengel (Malak Sagad) (csco, 20; Aeth., 3), Parisiis, 1907, p. 121].

14 At least we have no data about that.

15 <http://www.ethiopianorthodox.org/amharic/holybooks/readings/ginbotgitsawe.pdf> (accessed on February 6, 2018).

16 Cf., for instance: I. Guidi (ed.), Annales Iohannis I, Iyasu I, Bakaffa (csco, 22; Aeth. 5) Parisiis, 1903 , p. 83 (during the reign of Iyasu I). 